\title{
POLA ASUH ORANG TUA TERHADAP PERKEMBANGAN ANAK BERDASARKAN GENDER
}

\author{
Siti Rabiatul Adawiyah
}

\begin{abstract}
Children need education to increase their roles in society. Children education through formal, non-formal, and/or informal education is held to improve the quality of children's skills. Given the huge and importance of the process of parenting education, hence this study aims to determine the influence of parenting on children. Children are great blessings people must be grateful for, hence they deserve the best parenting by their parents. However, parents still treat their children differently. This discussion aims to identify various styles or methods of parenting and their impacts on children. This discussion consisted of four types of parenting proposed by Eisenburg et al. These parenting types are more specific and focused on children's gender development than other parenting styles that are more general. The four types of parenting are channeling/shaping, direct introduction, differential treatment, and models. There are four types of parenting model according to some psychologists, which are authoritative parenting, neglectful parenting, permissive parenting, and democratic parenting. These four types have their own impacts. While some other opinions believe that authoritative parenting style has 6 (six) parenting styles, which are: Accept children's opinion, Ask about children's mistakes without accusing them, Give advice upon their mistakes, Give appreciation, Give presents, and Facilitate their hobbies.
\end{abstract}

Keywords: Gender, Parenting Style, Children

\section{PENDAHULUAN}

Keluarga merupakan pendidikan pertama bagi anak untuk menentukan optimalisasi perkembangan pribadi, penyesuaian diri, kemampuan bersosialisasi, kecerdasan, kreativitas, moral juga peningkatan kapasitas diri menuju batas-batas kebaikan dan kemampuan dalam ukuran kemanusiaan. Keluarga merupakan sub sistem dari masyarakat, keluarga memiliki fungsi strategis dalam menanamkan 
nilai-nilai kesetaraan dalam setiap aktivitas dan pola relasi antar anggota keluarga karena dalam keluargalah semua struktur, peran dan fungsi sebuah sistem berada. Oleh karena itu, keluarga menjadi institusi yang penting bagi anak didalam mengembangkan perilaku-perilaku tertentu dalam kehidupannya. ${ }^{1}$

Keluarga, hendaknya menjadi tempat paling aman, damai dan tentram bagi seluruh anggotanya dan mengedepankan keadilan dalam peran dan pembagian kerja gender dalam keluarga (suami dan istri). Namun, berbagai persoalan yang terjadi dalam keluarga lebih disebabkan oleh konstruksi sosial dan kultural yang dipahami dan dianut oleh masyarakat yang tidak didasarkan pada asas kesetaraan gender, sehingga yang mengakibatkan beban ganda (double burden) bagi istri (wanita). Pemahaman tentang subyek-obyek, dominan-tidak dominan, superiorimperior serta pembagian peran-peran yang tidak seimbang antara anggota keluarga laki-laki (ayah, anak laki-laki) dan perempuan (ibu, anak perempuan). ${ }^{2}$

Pada beberapa budaya, khususnya pada budaya di Timur Tengah keberadaan dan kelahiran anak laki-laki lebih diharapkan ketimbang anak perempuan. Pada budaya timur tengah, anak laki-laki mewakili simbol kepimpinan, kekuatan, dan kewibawaan keluarga. Dari kondisi diberbagai negara tersebut, dapat digaris bawahi walaupun modernitas sudah berkembang sedemikian pesat dan teknologi sudah semakin canggih, namun harapan akan jenis kelamin tertentu pada anak masih tetap ada da tetap didominasi oleh harapan lahir anak laki-laki ketimbang perempuan. ${ }^{3}$

Tidak berhenti pada harapan orang tua tentang jenis kelamin anak yang akan dilahirkan, ada hal lain yang dilakukan oleh orang tua terhadap anaknya dalam kaitannya terhadap perkembangan gender sang anak. Salah satu hal yang paling kuat mempengaruhi perkembangan gender anak yang dilakukan oleh orang

\footnotetext{
${ }^{1}$ Elida Prayitna. Psikologi Perkembangan. (Jakarta: Depdikbud, 1992), 75.

${ }^{2}$ Haris Herdiansyah, Gender Dalam Perspektif Psikologi (Jakarta: Salemba Humanika, 2016)

${ }^{3}$ Fakih, M , Analisis Gender dan Transformasi Sosial. (Yogyakarta: Pustaka Belajar, 2010), 101.
} 
tua adalah jenis pengasuhan beserta polanya yang bervariasi yang sangat kental mempengaruhi perkembangan gender anak.

Berdasarkan pada paparan diatas, jenis pengasuhan orang tua sangatlah berpengaruh baik psikologis sang anak maupun mempengaruhi perkembangan gender anak.

\section{PEMBAHASAN}

\section{Konsep Gender}

Kata gender berasal dari bahasa inggris berarti jenis kelamin. Namun jenis kelamin di sini bukan seks secara biologis, melainkan sosial budaya dan psikologis. Gender diartikan sebagai perbedaan yang tampak antara laki-laki dan perempuan dilihat dari segi nilai dan tingkah laku, Pada prinsipnya, konsep gender memfokuskan perbedaan peranan antara laki-laki dengan perempuan, yang dibentuk oleh masyarakat sesuai dengan norma sosial dan nilai sosial budaya masyarakat yang bersangkutan. Jadi gender bukan bicara perbedaan jenis kelamin antara laki-laki dan perempuan melainkan peranan yang dimainkan oleh laki-laki dan perempuan dalam kehidupan bermasyarakat. ${ }^{4}$

\section{Pengertian Orang Tua}

Orang tua adalah orang dewasa yang memikul tanggung jawab pendidikan, sebab secara alami anak pada masa awal-awal kehidupannya berada ditengah-tengah ayah dan ibunya. Dan dari merekalah anak mulai mengenal pendidikan $^{5}$.

Rumah tangga merupakan pusat kasih sayang dan saling membantu antar sesama anggotanya, telah menjadi lembaga teramat penting sebagai pendidikan anak. Oleh karena itu, maka orang tua adalah paling bertanggung jawab terhadap pendidikan anaknya. Apalagi sejak dilihat sejak masa anaknya dalam kandungan merekalah yang paling setia -terutama ibu-menjaga, merawat dan mengasuh.

${ }^{4}$ Eagly, A.H., A.E Beal dan R.J Sternberg. The Psychology Of Gender, (London : The Guilford Press, 2004).

${ }^{5}$ Hery Noer Aly, Ilmu Pendidikan Islam, (Jakarta: PT. Logos Wacana Ilmu, 1990), 87. 


\section{Pola Pengasuhan Orang Tua}

Dilihat dari kecamata agama ternyata bahwa Islam telah menggariskan konsep-konsep yang jelas mengenai pendidikan anak. Pada tingkat pertama, Islam menjelaskan bahwa yang paling sayang dan cinta kepada anak adalah orang tuanya, yang dimaksudkan dengan orang tua disini adalah ayah dan ibu kandung anak yang dididik. Memang, di dalam realitas empirik memang terlihat bahwa karena kasih sayang dan cinta itu maka orang tua bersedia berkorban sampai ketingkat optimal untuk memenuhi kebutuhan anak-anaknya. Hal itu telah terbukti kebenarannya dalam realita kehidupan manusia kecuali dalam kalangan orang tua yang mempunyai kelainan jiwa. Al-Quran menggambarkan kasih sayang orang tua kepada anak dengan berbagai cara, antara lain Allah Swt berfirman yang artinya: harta dan anak-anak adalah hiasan hidup di Dunia (Q.S. Al-Kahf : 46). Dalam surat lain Allah Swt berrfirman pula yang artinya: Dan kami membantumu dengan harta kekayaan dan anak-anak dan kami menjadikanmu kelompok yang besar (Q.S. Al-isra' : 6).

Pola berarti gambaran yang dipakai untuk memberi contoh. Sedangkan asuh berarti menjaga, merawat, mendidik anak kecil atau memimpin, membantu, melatih supaya dapat berdiri sendiri. Hetherington dan Parks menjelaskan bahwa pola asuh dapat diartikan sebagai interaksi antara dua dimensi perilaku orang tua. Dimensi pertama adalah hubungan emosional antara orang tua dan anak. Dimensi kedua adalah cara-cara orang tua dalam mengontrol perilaku anak. Orang tua adalah setiap orang yang bertanggung jawab dalam suatu keluarga atas rumah tangga yang dalam kehidupan sehari-hari di sebut dengan ayah dan ibu.

Pola asuh orang tua adalah suatu keseluruhan interaksi antara orang tua dengan anak, di mana orang tua bermaksud menstimulasi anaknya dengan mengubah tingkah laku, pengetahuan serta nilai-nilai yang dianggap paling tepat oleh orang tua, agar anak dapat mandiri, tumbuh dan berkembang secara sehat dan optimal. Perkembangan kognitif adalah kempuan berpikir anak melalui pemahaman terhadap konsep, penyesuaian dan kemampuan menyelesaikan 
permasalahan. ${ }^{6}$ Pola asuh adalah suatu gaya mendidik, yang dilakukan oleh orang tua untuk membimbing dan mendidik anak- anaknya dalam proses interaksi yang bertujuan untuk memperoleh suatu peilaku yang diinginkan ${ }^{7}$. Pola asuh merupakan sebagai didikan dimana orang tua seing berembuk mengenai tindakantindakan yang harus diambil, menerangkan alasan-alasan daripada peraturan, menjawab kepada pertanyaan-pertanyaan anak dan bersikap toleran.

Dari beberapa pendapat ahli tersebut dapat disimpulkan bahwa pola asuh orang tua merupakan pola interaksi orang tua selama melakukan kegiatan pengasuhan berupa sikap yang dapat dilihat dari berbagai segi antara lain cara orang tua mendidik, membimbing, menerapkan aturan dan disiplin, membeikan hadiah dan penghargaan, hukuman, serta cara menunjukkan kekuasaannya, perhatian. dan tanggapan atas keinginan anak serta cara berhubungan dan berkomunikasi dengan anak baik secara langsung maupun tidak langsung.

Undang-Undang Nomor 20 Tahun 2003 tentang Sistem Pendidikan Nasional bahwa pola asuh merupakan pola pengasuhan yang berlaku dalam keluarga. Perbedaan dalam konsep ini adalah ketika anak dilihat sebagai sosok yang sedang berkembang, konsep pengasuhan ini untuk mempertahankan caracara yang tertanam di dalam keluarga maupun lingkungan masyarakat. ${ }^{8}$

Aspek-aspek yang menjadi Indikator dalam pola asuh orang tua perspektif gender meliputi Nilai anak Yaitu terkait dengan cara orang tua memperlakukan anak-anaknya baik dari sisi psikologi, ekonomi, dan sosial. Pembagian tugas pengasuhan yaitu meliputi bagaimana cara ayah dan ibu dalam membagi dan bekerjasama dalam mengasuh anak, Perlakuan teknis pengasuhan yaitu berkaitan dengan cara orang tua dalam membagi tugas- tugas rumah tangga kepada anakanaknya; Harapan tentang masa depan yaitu terkait dengan bagaimana orang tua memberi kesempatan dan memberi dukungan perkembangan potensi anak-

\footnotetext{
${ }^{6}$ Hetherington dan Parks, 2000, Dikutip oleh D.Dianasari", Hubungan antara Kedemokrasian Pola Asuh Orang Tua dengan Kompetensi Sosial pada Remaja, (Yogyakarta, Skripsi Fakultas Psikologi Universitas Gadjah Mada Yogyakarta, 2000), 42.

${ }^{7}$ Gunarsa Singgih. D., Psikologi Anak dan Remaja, (Jakarta: Gunung Mulia, 1990), 5.

${ }^{8}$ Depdiknas, UU No. 20 Tahun 2003 Tentang sistem pendidikan nasional, (Bandung: Citra Umbara, 2003).
} 
anaknya pengambilan keputusan. yaitu pembagian wewenang antara ayah dan ibu dan proses pengambilan keputusan.

Pengasuhan anak akan memberikan hasil yang lebih baik jika ayah dan ibu menjalankan pengasuhan secara bersama. Kebersamaan tersebut disertai dengan sikap yang mendukung dan bertindak sebagai satu tim yang selalu bekerja sama dan tidak saling bertentangan, meskipun peran yang dilakukan berbeda. Rotenberg yang menyatakan bahwa ibu berperan membentuk keyakinan tentang pentingnya kepercayaan dan ayah berperan membentuk perilaku untuk mempercayai. ${ }^{9}$

Pengasuhan bersama ini akan membawa hasil yang baik jika dilakukan secara responsif gender, yaitu pengasuhan yang respon terhadap perbedaan aspirasi, kebutuhan dan pengalaman perempuan dan laki-laki yang tujuannya mewujudkan keadilan dan kesetaraan gender. Keadilan dan kesetaraan gender ini menghendaki sebuah relasi yang egaliter, demokratis dan terbuka, serta ditandai rasa hormat dan saling menyayangi antara yang tua dengan yang muda dan antara laki-laki dan perempuan sebagai anggota keluarga sehingga semua mendapatkan hak dasar sebagai manusia. ${ }^{10}$

Pola asuh responsif gender berkaitan dengan pemahaman dalam menata ${ }^{11}$.

a. lingkungan fisik,

b. lingkungan sosial, internal dan eksternal,

c. Pendidikan internal dan eksternal,

d. dialog dengan anak-anak,

e. suasana psikologis,

f. sosiobudaya,

g. perilaku yang ditampilkan pada saat terjadinya pertemuan dengan anakanak, serta

h. kontrol terhadap perilaku anak-anak

\footnotetext{
${ }^{9}$ Lestari, S, “Psikologi Keluarga”, (Jakarta: Kencana. 2014).

${ }^{10}$ Dewi, S.M., "Pengembangan Model Pembelajaran Responsif Gender di PAUD Ainina Mejobo Kudus", dalam Jurnal Thufula PGRA STAIN Kudus, Volume 1, Nomor 1 (2013): 127.

${ }^{11}$ Kementerian Pendidikan dan Kebudayaan, Pengarusutamaan Gender Buku I: Panduan Pembinaan Keluarga yang Responsif Gender, Jakarta: Direktorat Jenderal Pendidikan Anak Usia Dini, Nonformal, dan Informal \& Direktorat Pembinaan Pendidikan Masyarakat, 2014.
} 
Pemahaman pola asuh responsif gender diungkap dengan instrumen PARG yang terdiri dari 48 item pernyataan dengan skor maksimal adalah 192. Didasarkan pada item yang diisi, responden dapat diklasifikasikan menjadi 4 kategori yaitu Sangat Responsif (SR), Responsif (R), Cukup Responsif (CR), dan Tidak Responsif (TR). Kategori CR dan TR dikatakan sebagai golongan responden yang belum sepenuhnya responsif, artinya masih memunculkan bias gender pada pengasuhannya. Katogori pemahamana tersebut didasarkan pada aspek bebas tidaknya pengasuhan dari komponen stereotipe, subordinasi, dan marginalisasi.

Perkembangan kognitif pada usia sekolah mengikuti tahapan perkembangan kognitif pada tahap konkret operasional. Oleh karena itu, kemampuan kognitif berhubungan dengan kemampuan kemandirian anak kelak saat dewasa. Penelitian ini bertujuan untuk menganalisis pengaruh pola asuh berdasarkan gender dan motivasi belajar terhadap perkembangan kognitif anak sekolah dasar. Pola asuh berdasarkan gender mencakup 3 dimensi yaitu pola asuh sehat, pola asuh makan dan pola asuh belajar.

Dalam ilmu psikologi, beberapa ahli psikologi perkembangan sudah sangat jelas mengungkapkan beberapa pola pengasuhan yang berbeda-beda yang masing-masing memiliki cara dan pendekatannya masing-masing dari orang tua terhadap anaknya. Sebut saja dengan empat jenis pola asuh yang dikemukakannya, yakni pola asuh demokratis, pola asuh permisif, pola asuh otoriter, dan pola asuh penelantar. Tentu saja, setiap pola asuh tersebut mempunyai efek tertentu yang bukan hanya mempengaruhi psikologis sang anak, tetapi juga mempengaruhi perkembangan gender anak. ${ }^{12}$ Adapun penjelasan dari keempat jenis pola asuh tersebut :

\section{a. Pola asuh Otoriter}

Tipe pola asuh anak yang pertama ini menjadikan orang tua sebagai pemegang kekuasaan tertinggi (otoriter) dan mendominasi dalam mengasuh anak.Karakteristik otoriter, yaitu kaku, tegas, menerapkan hukuman jika tidak

\footnotetext{
${ }^{12}$ Baumrind, D. The Influence Of Parenting Style On Adolescent Competence And Substance Use. The Journal of Early Adolescence, 11 (1), 56-95. (1991).
} 
sesuai aturan. Orang tua cenderung selalu benar dalam mengemukakan pendapat. Pola asuh ini akan membentuk seorang anak dengan karakter disiplin dan patuh. Namun sayangnya, orang tua yang otoriter sering melayangkan ungkapan "pokoknya" ketika sedang mengutarakan pendapat, tanpa memedulikan atau mendengar pendapat dan keinginan anak. Hal ini dapat membuat anak menjadi tidak terbiasa membuat keputusan sendiri dan takut jika tidak menuruti perkataan orang tuanya. Selain itu, anak yang terbiasa dengan pola asuh otoriter sering kali sulit mengungkapkan pendapatnya sehingga muncul masalah kecemasan yang dapat menyebabkan stres.

Dampak pola asuh otoriter terhadap perkembangan anak lainnya, yakni dapat membuat emosi anak meledak-ledak, hubungan interpersonal (dengan orang lain) yang kurang baik, dan cenderung menjadi pribadi yang otoriter di kemudian hari.

b. Pola asuh permisif

Pola asuh anak permisif berlawanan 180 derajat dari pola asuh otoriter. Pola ini dikenal dengan karakteristik memanjakan anak atau "serba boleh". Orang tua permisif menjadi seorang teman baik bagi anaknya karena memberikan perhatian, kehangatan, dan interaksi yang cukup baik.

Ciri lainnya dari pola asuh ini, yakni orang tua selalu mendorong anaknya untuk berbuat bebas, semaunya, mewujudkan apa yang anak mau, dan tidak memberikan batasan pada anak sehingga jarang mendisiplinkan.

Anak yang tumbuh dengan pola asuh permisif memang tumbuh kreatif karena terbiasa bebas mengekspresikan dirinya. Namun, dalam jangka panjang, anak menjadi bingung karena tidak terbiasa dengan batasan yang ada. Hal tersebut dapat membuat anak menjadi sulit menyesuaikan diri dengan lingkungan, bersifat egois, menuntut, cenderung memberontak, dan motivasi belajar yang kurang.

c. Pola asuh

Pola asuh demokratis merupakan pola asuh yang paling baik. Hal ini didukung oleh penelitian dari UGM yang membuktikan, pola asuh orang tua yang demokratis dapat mencegah anak memiliki masalah kepribadian. Bisa dibilang pola asuh demokratis merupakan kombinasi antara pola asuh otoriter dan juga 
permisif. Anak diberikan batasan dan konsekuensi yang konsisten ketika batasan tersebut dilanggar. Tujuan batasan dan konsekuensi dijelaskan pada anak sehingga komunikasi juga tetap terjaga dengan baik.

Di luar itu, orang tua tetap memberikan pujian, dukungan emosional, dan hadiah jika anak dapat meraih suatu prestasi. Komunikasi antara orang tua dan anak terjalin baik sehingga anak juga menjadi jujur, tetapi tetap patuh.

Pola asuh ini menjadikan anak memiliki kepribadian yang seimbang, mandiri dalam mengambil keputusan, disiplin dengan mempunyai komunikasi baik, memiliki rasa percaya diri, kreatif, dan bahagia secara psikologis. Karakteristik tersebut dipercayai dapat menjadi kunci kesuksesan seorang anak di kemudian hari.

d. Pola asuh penelantar (Cuek)

Pola asuh cuek atau abai sering terjadi pada orang tua yang terlalu sibuk atau memiliki masalah pribadi, seperti masalah keuangan, kecanduan narkoba, alkohol, atau judi.

Pada tipe pola asuh anak ini, orang tua hanya memenuhi kebutuhan fisik dasar anak saja, seperti makan, tempat tinggal, dan pakaian. Sementara itu, kebutuhan secara psikologis dan emosional jarang terpenuhi karena orang tua menjadi tidak peduli dan jarang berinteraksi dengan anaknya.

Pada pola asuh ini, tidak jarang jika anak lebih banyak dididik oleh gawai, televisi, atau video games. Saat kecil, mungkin anak belum sadar atas ketidakacuhan orang tuanya. Namun, lambat laun anak menjadi sadar bahwa dirinya tidak penting dalam hidup orang tuanya sehingga cenderung menjadi anak yang mandiri.

Hal ini tidak sepenuhnya baik karena anak yang tumbuh dengan pola asuh cuek cenderung menyebabkan anak bermasalah di kemudian hari, nilai akademis yang buruk, emosi yang tidak terkontrol, serta kesulitan menjalin relasi dan komunikasi.

Pada bahasan kali ini, jenis pengasuhan yang akan saya angkat adalah jenis pengasuhan yang dikemukakan oleh Eisenberg bersama kolega-koleganya yang terdiri atas empat jenis yang menurut saya, jenis pengasuhan ini lebih spesifik dan 
difokuskan pada perkembangan gender anak ketimbang pola pengasuhan lain yang lebih bersifat umum. Berikut keempat jenis pengasuhan yang dikemukakan oleh Channeling/Shapping.

Pada jenis ini, orangtua menciptakan dunia tersendiri bagi anak yang sudah mengarahkan anak pada gender tertentu berdasarkan pada jenis kelaminnya. Mulai dari memberikan nama anak sesuai jenis kelaminnya, membelikan baju, dan mainan sesuai jenis kelaminnya, memilih pekerjaan rumah yang disesuaikan dengan jenis kelamin anak, dan sebagainya. Jenis pengasuhan channeling memungkinkan orangtua mengambil kendali sepenuhnya atas anak dan segala aktivitas yang anak lakukan yang berorientasi pada jenis kelamin anak yang bersangkutan. Orangtua dengan pola asuh ini benar-benar mensterilkan anak dari segala hal yang bukan porsinya dan bukan ranah jenis kelaminnya. Pendidikan gender terlihat sangat rigid dan dikotomi.

\section{a. Differential Treatment}

Orangtua dengan jenis pengasuhan ini membedakan perlakuan antara anak laki-laki dengan perempuan yang difokuskan pada interaksi orangtua anak disertai dengan konsekuensinya yang cukup tegas. Orang tua berinteraksi dan berbicara dengan kalimat dan tone yang berbeda antara anak laki-laki dan anak perempuannya.

Dalam hal hukuman, anak laki-laki diberikan hukuman fisik sementara berbeda dengan hukuman anak perempuan yang lebih diberi hukuman berupa verbal atau emosional. Anak laki-laki dididik untuk tidak boleh cengeng, harus melindungi saudaranya yang perempuan. Anak laki-laki lebih sering diceritakan tentang cerita heroik sementara anak perempuan lebih banyak diceritakan tentang hubungan yang baik dan romantis.

\section{b. Direct Instruction}

Pola pengasuhan ini sangat memperhatikan dan mempertimbangkan norma sosial. Orang tua dalam mengasuh dan mengajarkan sesuatu kepada anaknya agr anak-anak mereka lebih bisa diterima dilingkungan sosialnya dan sesuai dengan tuntutan lingkungan sosial. Orangtua mengajarkan anak laki-laki untuk tidak cengeng karena secara sosial anak laki-laki dituntut untuk tidak cengeng. Anak 
perempuan dididik untuk mampu mengerjakan pekerjaan domestik dan pandai memasak karena secara sosial kemampuan domestik lebih dituntut pada anak perempuan.

c. Models

Pada pengasuhan ini menjadikan orangtua sebagai untuk anak melakukan imitasi. Semua perilaku dilakukan agar anaknya melihat secara langsung dan menginternalisasi pembelajaran melalui apa yang orang tua contohkan. Ketika orangtua hendak mengajarkan konsep relasi antar gender maka yang dijadikan contoh adalah perilaku konkret ayah-ibu mereka sendiri. Bahkan pada titik tertentu, misalnya orangtua ingin mendidik mengenai power dan kepimpinan. Sang ayah berusaha menjadi pemimpin yang baik dlingkungan rumah atau diluar rumah. Jelas bahwa ayah dan ibu adalah aktor utama dalam segala hal pendidikan yang diterima oleh anak dirumah, termasuk didalamnya pembelajaran mengenai Gender. Selain itu segala bentuk perilaku orangtua, merupakan "materi pembelajaran" bagi anak pun dalam hal perilaku yang berbeda yang dimunculkan ayah dan ibu yang mewakili gendernya masing-masing akan menjadi pembelajaran bagi anak bagaimana seorang perempuan berperilaku dan berlasi dengan anak dengan laki-laki dan sebaliknya. ${ }^{13}$

Bagaimana seorang perempuan dan laki-laki berperilaku dan berelasi dengan anak-anak mereka, bahkan dengan lingkungan sekitar yang diwakili oleh perilaku ayah dan ibunya dirumah. Menurut Perspekti Teori Pembelajaran Sosial (Social Learning Theory) ini terkait dengan proses modeling atau imitasi.

Pola pengasuhan ini oleh sebagian oleh ahli gender dipandang sebagai pola pengasuhan yang kompleks sekaligus lebih sulit karena disisi lain, orangtua juga harus berusaha mengubah diri untuk menjadi contoh yang baik bagi anakanaknya.

Dari keempat pola pengasuhan yang dikemukakan oleh Eisenberg bersama koleganya tidak dikatakan mana yang lebih baik dan mana yang kurang baik. Kesemuanya dianggap positif daan tidak menutup kemungkinan dalam keluarga

${ }^{13}$ Chosak, S. Your Living Legacy: How Your Parenting Style Shapes The Future For You And Your Child Sarasota: Design Publishing. Inc. 2015. 
menerapkan lebih dari satu pola pengasuhan. Situasi, kondisi dan konteks budaya setempat memainkan peran yang mempengaruhi peran orangtua dalam menerapkan pengasuhan. Keempat pola pengasuhan tersebut dapat memunculkan dinamika yang berbeda-beda sepanjang rentang pengasuhan. Boleh jadi beberapa pola pengasuhan yang diterapkan sesuai dengan usia fase perkembangan anak dan kesiapan orangtua dalam memberikan pengasuhan.

Orangtua modern mempunyai karakteristik mencoba-coba (trial and error) terhadap banyak hal termasuk dalam hal pola pengasuhan. Mereka masih mencarimencari pola pengasuhan yang sesuai dengan kondisi dan karakteristik pola kehidupan yang mereka terapkan.

Melalui pengasuhan yang responsif gender, sumber daya manusia yang dihasilakan akan lebih matang dan dewasa secara fisik dan psikososia, karena pengasuhan dilakukan memperhatikan tugas -tugas perkembangan anak dengan memperhatikan kebutuhan akan pertumbuhan dan perkemabngan potensi anak sesuai dengan keberfungsian yang bisa berkolaborasi dalam menjalini kehidupan. Sebagiamana pernyataan Munif Chatib "yakinlah...setiap anak punya harta karun didalam dirinya, seperti pesan yang diditipkan Allah kepada dirinya. Tugas orang tua hanya membantu menemukannya, lalu kondisi terbaik anak kita akan menerangi dunia"14 ntuk itu dalam meyelenggarakan pendidikan keluarga responsif gender, dapat menggunakan beberapa metode diantaranya;

1) keteladanan,

2) pembiasaan,

3) pembinaan,

4) kisah, 5) dialog,

6) ganjaran dan hukuman,

7) dan metode internalisasi ${ }^{15}$.

Berbagai metode ini dapat dikolaborasikan dalam mengembangkan potensi terbaik anak, tanpa adanya bias gender dalam pelaksanaannya.

\footnotetext{
${ }^{14}$ Munif Chatib. Sekolahnya Manusia, (Bandung : Kaifa, 2009), 71.

${ }^{15}$ Helmawati, Pendidikan Keluarga, (Bandung: Remaja Rosdakarya, 2014), 60.
} 
Berdasarkan uraian diatas, pola asuh memiliki dimensi dalam pengasuhan orang tua bagaimana cara memperlakukan dan menjaga anaknya. Dimensi tersebut adalah Kehangatan (warmth) dan Kontol (control). Dimensi kontrol sendiri memiliki lima aspek yang berperan, yaitu pembatasan, tuntutan, sikap ketat, campur, dan kekuasaan yang sewenang-wenang.

Metode pola asuh orang tua dapat dikategorikan sebagai pola asuh permisif yaitu pola asuh orang tua terhadap anak maknanya orang tua harus bisa merangkul, memaafkan, menasehati, pemberian reward jika anak berbuat kebaikan dan berprestasi, pola asuh lainnya bisa berupa tegas, otoriter, dan pola asuh yang lepas ${ }^{16}$. Seperti pada gambar berikut:

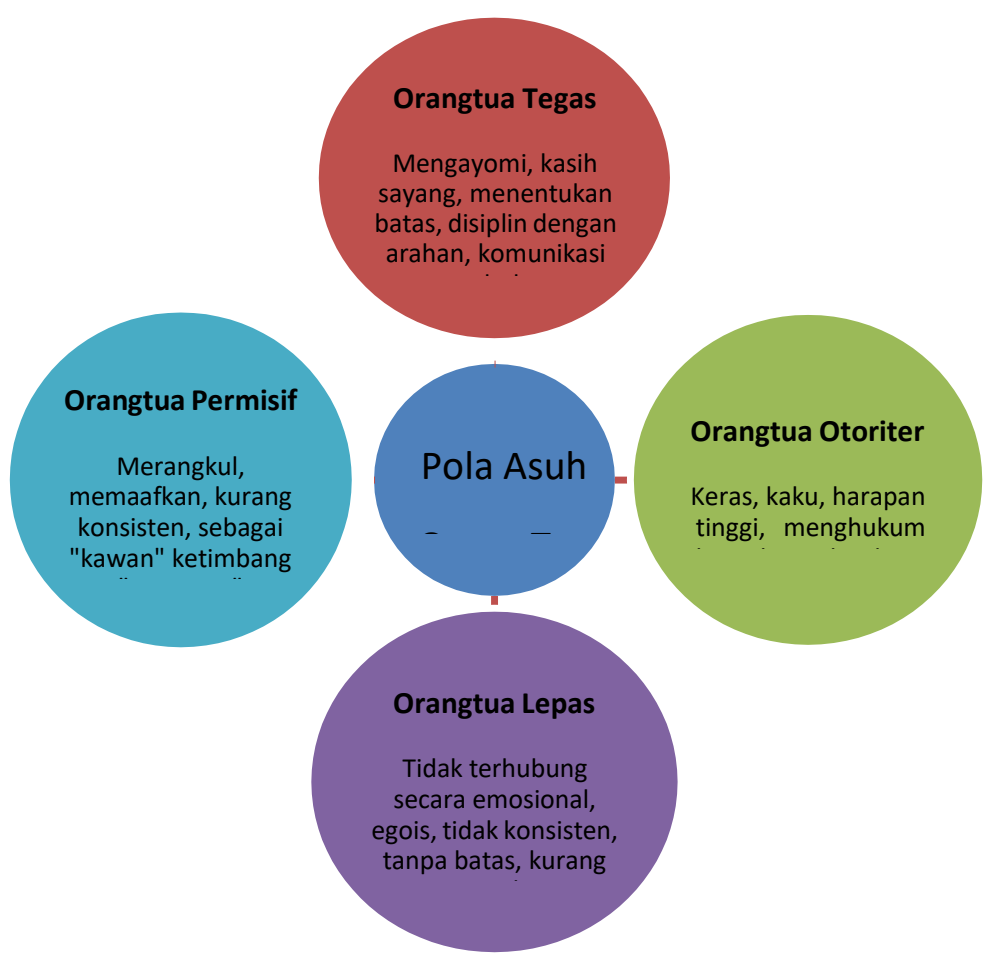

Konsep pola asuh orang memberikan pengaruh terhadap pembentukan kepribadian anak. Pola asuh adalah suatu gaya mendidik untuk membimbing

${ }^{16}$ Luo, R., LeMondaa, C.S., Song, L. Chinese parent's goals and practices in early childhood, Early Childhood Research Quarterly, 28, 843-857. 2013. 
anak-anaknya dalam proses interaksi yang bertujuan agar anak memiliki perilaku yang diinginkan orang tua. Pola asuh adalah konsep dasar tentang cara memperlakukan anak. Perbedaan dalam konsep ini adalah ketika anak dilihat sebagai sosok yang sedang berkembang, konsep pengasuhan ini untuk mempertahankan cara-cara yang tertanam di dalam keluarga maupun lingkungan masyarakat. $^{17}$

Pola asuh adalah cara atau metode pengasuhan yang digunakan oleh orang tua agar supaya anak-anaknya dapat tumbuh menjadi individu-individu yang dewasa secara sosial. Sebagai pengasuh dan pembimbing dalam keluarga, orang tua sangat berperan dalam meletakkan dasar-dasar perilaku bagi anak-anaknya kelak. Segala sikap dan perilaku baik atau buruk orang tua secara langsung maupun tidak langsung akan berpengaruh terhadap perkembangan anak secara sosial bahwa bentuk pola asuh orang tua khusus tentang authoritative memiliki 6 (enam) model pola asuh orang tua antara lain: Menerima pendapat anak, Menanyakan kesalahan anak tanpa memarahi, Memberikan nasehat ketika berbuat salah, Memberi pujian, Memberi hadiah, Memfasilitasi hobby. ${ }^{18}$ Orang tua memberikan kesempatan anak untuk mengembangkan kemampuan daya nalar dan imajinasi ini agar membantu anak lebih memahami nasehat yang diajarkan. ${ }^{19}$

Pola asuh orang tua dalam 6 metode yang bersifat Authoritative yaitu menerima pendapat anak ketika melakukan communication, Menanyakan apa yang terjadi tanpa memarahinya, Memberikan nasihat kepada anak ketika berbuat salah, Memberi pujian ketika anak berkelakuan baik, Memberi hadiah ketika anak pintar di sekolah dan Memfasilitasi hobi yang positif yang disukai anak dapat berdampak pada ketaatan anak pada orang tua. Makna ketaatan adalah mentaati

\footnotetext{
${ }^{17}$ Chosak, S. (2015). Your living legacy: how your parenting style shapes the future for you and your child. Sarasota: Design Publishing. Inc

${ }^{18}$ Kipp. K \& Shaffer R. D Developmental psychology childhood and adolescence. United Stated Of America : Jon-David Hague. 2014

${ }^{19}$ Wahyudi, D., \& Wardani, Septya, D. Akhlak Melalui Multimedia Lcd Proyektor Dedi Wahyudi Devi Septya Wardani. Didaktika, 18(1), 1-15. (2017).
} 
kedua orang tua dengan melakukan semua apa yang mereka perintahkan selama hal tersebut tidak bermaksiat kepada Allah SWT. ${ }^{20}$

4. Faktor-Faktor Yang Mempengaruhi Pola Asuh Orang Tua

Beberapa faktor yang mempengaruhi pola asuh menurut Edward10, yakni: Tingkat pendidikan dan pengetahuan orang tua serta pengalaman sangat berpengaruh dalam mengasuh anak, Lingkungan, budaya, Stress ibu dalam menjalankan pola asuh, hubungan suami istri yang kurang harmonis, Aktivitas ibu sangat mempengaruhi hubungan dengan anggota keluarga terutama anak, faktor usia karena terlalu muda ataupun tua, menyebabkan tidak dapat menjalankan peran secara optimal.

Pola asuh keluarga lebih banyak dipegang oleh ibu dirumah, namun terdapat beberapa faktor yang mempengaruhi pola asuh yaitu; Tingkat Pendidikan dan pengetahuan orang tua serta pengalaman sangat berpengaruh dalam mengasuh anak, seperti: terlibat aktif dalam pendidikan anak, mengamati segala sesuatu dengan berorientasi pada masalah anak, selalu berupaya menyediakan waktu untuk anak-anak dan menilai perkembangan fungsi keluarga dalam keperawatan anak lingkungan,banyak mempengaruhi perkembangan anak, maka tidak mustahil jika lingkungan ikut serta mewarnai pola-pola pengasuhan yang diberikan orangtua terhadap anaknya.

Anak juga seringkali mengamati perilaku orang lain, kemudian menjadi ciri kebiasaan atau kepribadiannya. Budaya orangtua sering mengikuti cara-cara yang dilakukan masyarakat dalam mengasuh anak, karena dianggap dianggap berhasil dalam mendidik anak dan diharapkan anak dapat diterima masyarakat dengan baik. Orangtua juga menjadikan pedoman praktik pengasuhan dari orangtua mereka sendiri, strategi penyelesaian masalah yang dimiliki dalam menghadapi permasalahan anak, hubungan suami-istri yang kurang harmonis akan berdampak kepada kemampuan ibu dalam memberikan pola asuh secara bahagia aktifitas ibu sangat mempengaruhi hubungan dengan anggota keluarga terutama anak-anaknya.

${ }^{20}$ Fika Pijaki, N., Agustina, S. M., Lutfiah, V. L., \& Yulianti, W. Konsep Pendidikan Birrul Walidain Dalam Qs . Luqman. Didaktika, 18 (1), 16-31. 2017. 
80 | MUSAWA, Vol. 13 No.1 Juni 2021 : 65-81

\section{KESIMPULAN}

Berdasarkan pembahasan terkait perspektif gender pada pola asuh orang tua bagi perkembangan anak, maka dapat disimpulkan hal-hal sebagai berikut:

1. Bahwa pola asuh berdasarkan Diana Buamrind dengan empat jenis pola asuh yang dikemukakannya, yakni pola asuh demokratis, pola asuh permisif, pola asuh otoriter, dan pola asuh penelantar.

2. Pola asuh dikemukakan oleh Eisenberg bersama kolega-koleganya yang terdiri atas empat jenis yaitu chanelling/shaping, direct instruction, diffrential teratment dan models, jenis pengasuhan ini lebih spesifik dan difokuskan pada perkembangan gender anak ketimbang pola pengasuhan lain yang lebih bersifat umum.

3. Bentuk pola asuh orang tua khusus tentang authoritative memiliki 6 (enam) model pola asuh orang tua antara lain: Menerima pendapat anak, Menanyakan kesalahan anak tanpa memarahi, Memberikan nasehat ketika berbuat salah, Memberi pujian, Memberi hadiah, Memfasilitasi hobby.

\section{DAFTAR PUSTAKA}

Baumrind, D. The influence of parenting style on adolescent competence and substance use. The Journal of Early Adolescence. 1991.

Depdiknas. UU No. 20 Tahun 2003 Tentang sistem pendidikan nasional. Bandung: Citra Umbara. 2003.

Eisenberg, N. S.A,Wolchik, R. Hernandes, dan J.F Pasternack. Parental Socialization ofyoung children's play A short-term longitudinal study" Journal Child Of Development. 1985.

Eisenberg, N.S.A Cumberland dan T.L Spinrad, 1998. "Parental Socializationof emotion" Psychological Inquiry. 1998.

Elida Prayitno. Psikologi Pekembangan.Jakarta: Departemen Pendidikan dan Kebudayaan. 1993.

Fakih, M. Analisis Gender dan Transformasi Sosial. Yogyakarta: Pustaka Pelajar.2010 
Fika Pijaki, N., Agustina, S. M., Lutfiah, V. L., \& Yulianti, W. Konsep Pendidikan Birrul Walidain Dalam Qs . Luqman. Didaktika, 18(1), 16-31. 2017.

Hetherington dan Parks, Dikutip oleh D.Dianasari", Hubungan antara Kedemokrasian Pola Asuh Orang Tua dengan Kompetensi Sosial pada Remaja, Yogyakarta, Skripsi Fakultas Psikologi Universitas Gadjah Mada Yogyakarta, 2000.

Kementerian Pendidikan dan Kebudayaan, Pengarusutamaan Gender Buku I: Panduan Pembinaan Keluarga yang Responsif Gender, Jakarta: Direktorat Jenderal Pendidikan Anak Usia Dini, Nonformal, dan Informal \& Direktorat Pembinaan Pendidikan Masyarakat.2014.

Kipp. K \& Shaffer R. D Developmental psychology childhood and adolescence. United Stated Of America : Jon-David Hague. 2014.

Munif Chatib. Sekolahnya Manusia. Bandung: Kaifa, 2009.

Lundberg, S dan E. Rose. "Child gender and transition to marriage."Journal Of Demography. no. 40.

Luo, R., LeMondaa, C.S., Song, L. Chinese parent's goals and practices in early childhood, Early Childhood Research Quarterly, 28, 843-857. 2013.

Purnama, Sigit. 2016. Materi-materi Pilihan dalam Parenting Education menurut Munif Chatib. Golden Age Jurnal Ilmiah Tumbuh Kembang Anak Usia Dini. Vol. I No. I

Wahyudi, D., \& Wardani, Septya, D. Akhlak Melalui Multimedia Lcd Proyektor Dedi Wahyudi Devi Septya Wardani. Didaktika, 18(1), 1-15. (2017).

Wang, X., Bernas, R., \& Eberhard, P. When a lie is not a lie: Understanding Chinese working-class mothers' moral teaching and moral conduct. Social Development, 21(1), 68-87. (2012). 